\title{
ENDOMETRIAL AND EMBRYONIC ENZYME ACTIVITIES IN RELATION TO IMPLANTATION IN THE EWE
}

\author{
E. S. E. HAFEZ* ANd I. G. WHITE \\ Department of Veterinary Physiology, University of Sydney, \\ Sydney, N.S.W., Australia
}

(Received 25th May 1967, revised 10th October 1967)

\begin{abstract}
Summary. The activity of alkaline phosphatase, acid phosphatase, glutamic-oxalacetic transaminase (GOT), lactic dehydrogenase (LDH), amylase, succinic dehydrogenase (SDH) and glucose-6-phosphate dehydrogenase (GPH) has been determined in the intercaruncular and caruncular areas of the endometrium during the follicular and luteal phases of the oestrous cycle and from 13 to 35 days of pregnancy in the ewe.

The activities of the enzymes in the two areas of the endometrium were similar except that alkaline phosphatase activity was higher, and SDH lower, in the intercaruncular area.

During the luteal phase of the oestrous cycle and during early pregnancy, alkaline and acid phosphatase activities increased in the intercaruncular and caruncular areas. Amylase and GOT values were also elevated in the caruncular area during early pregnancy. The level of LDH in the intercaruncular area of the endometrium was less during the luteal phase than during the follicular phase of the oestrous cycle.

Enzyme activity was variable in the chorion, embryo and blastocoelic fluid. The only statistically significant change was a sharp rise in the acid phosphatase concentration of the blastocoelic fluid at 31 to 35 days of pregnancy.
\end{abstract}

\section{INTRODUCTION}

In laboratory animals, fluctuations have been recorded in the level of a number of endometrial enzymes during early pregnancy, e.g. carbonic anhydrase (Lutwak-Mann \& Laser, 1954; Lutwak-Mann, 1955), lactic dehydrogenase, malic dehydrogenase and glutamic-oxalacetic transaminase (Delgado \& Fridhandler, 1964), $\beta$-glucuronidase (Prahald, 1962) and peptidase (Albers, Bedford \& Chang, 1961). It is not known, however, if these changes are essential for implantation and prenatal development or to what extent the results are applicable to the larger animals having a different type of placentation.

Some enzyme activities of the rabbit endometrium and embryo during

* Present address: Reproduction Laboratory, Department of Animal Sciences, Washington State University, Pullman, Washington, U.S.A. 
implantation are reported in a previous paper (Hafez \& White, 1967). This report describes fluctuations in the activity of a number of enzymes (alkaline phosphatase, acid phosphatase, glutamic-oxalacetic transaminase (GOT), lactic dehydrogenase (LHD), amylase, succinic dehydrogenase (SDH), glucose-6phosphate dehydrogenase (GDH)) in homogenates of sheep endometrium and embryos before and following implantation, and in homogenates of the intercaruncular (glandular) and caruncular (non-glandular) areas of the endometrium of non-pregnant ewes at different stages of the oestrous cycle.

\section{MATERIALS AND METHODS}

\section{Experimental animals}

Adult ewes and female lambs (Merino and crossbred) obtained from the University Farm or from a local dealer were run with a raddled vasectomized ram to establish the date of oestrus (Day 0 ). Some of the ewes were mated by fertile rams and slaughtered at appropriate intervals. Other non-pregnant ewes were killed during the follicular ( 0 to 3 days) and luteal ( 4 to 14 days) phase of the oestrous cycle.

\section{Preparation of tissues}

The uterus was removed as quickly as possible after slaughter and placed on crushed ice. All subsequent manipulation of the tissue was performed at $4^{\circ} \mathrm{C}$. The uterine horns were dissected from the connective tissue and opened from the antimesometrial side to release the conceptus. Blastocysts were separated into the chorion and blastocoelic fluid. Embryos with a crown-rump length of 10 to $15 \mathrm{~mm}$ were also collected; however, the umbilical cord, heart and liver were discarded in order to remove unwanted blood cells from the embryonic tissues.

The blastocyst-free uterus was cut open and any traces of chorionic tissue or uterine milk were removed by blotting the endometrium with filter paper. The superficial layers of the caruncular and the intercaruncular areas were dissected with fine forceps and scissors and then cut into smaller pieces.

\section{Enzyme analyses}

Samples of tissue $(0.5$ to $1 \mathrm{~g})$ were homogenized in 5 volumes of calcium-free Krebs-Ringer-tris, pH 7.4. A teflon Potter-Elvehjem homogenizer was found to be satisfactory, and after filtering the samples through cheese cloth, enzymes were assayed either directly or after appropriate dilution with buffer (Table 1). The assay procedures, except for succinic dehydrogenase, are set out in Bergmeyer (1963) which contains a discussion of the methodological errors.

$p$-Nitrophenylphosphate was used as the substrate for determining acid and alkaline phosphatase activity (Bessey, Lowry \& Brock, 1946; Andersch \& Szcypinski, 1947). One phosphatase unit is the amount of enzyme contained in 1 litre of homogenate which liberates $1 \mathrm{~m}$-mole $(139.11 \mathrm{mg}) p$-nitrophenyl at $37^{\circ} \mathrm{C}$.

Glutamic-oxalacetic transaminase activity was measured by determining the 
rate of formation of oxalacetate colorimetrically as the 2,4-dinitrophenylhydrazone (Reitman \& Frankel, 1956). The optical density at $546 \mathrm{~m} \mu$ was converted to GOT units from the table in Bergmeyer (1963). A GOT unit is the amount of transaminase in $1 \mathrm{ml}$ of homogenate which decreases the optical density of NADH at $340 \mathrm{~m} \mu$ by 0.001 in $1 \mathrm{~min}$, in a $3-\mathrm{ml}$ assay mixture at $25^{\circ} \mathrm{C}$ (LaDue, Wroblewski \& Karmen, 1954).

Lactic dehydrogenase activity was measured by the decrease of optical density at $340 \mathrm{~m} \mu$ due to oxidation of NADH in the presence of pyruvate. A unit is the amount of LDH which changes the optical density of NADH at $340 \mathrm{~m} \mu$ by 0.001 in $1 \mathrm{~min}$; in a $3-\mathrm{ml}$ assay mixture at 24 to $27^{\circ} \mathrm{C}$ (Wroblewski \& LaDue, 1955).

Amylase was estimated by the change in iodine colour of an amylase solution (Street \& Close, 1956) using one tenth of the volumes set out in Bergmeyer (1963) for the micromethod. Under our conditions one Street-Close unit would be contained in $10 \mathrm{ml}$ of homogenate when $0.1 \mathrm{ml}$ hydrolysed $0.2 \mathrm{mg}$ of amylase in 15 min at $\mathrm{pH} 7 \cdot 0$ and $37^{\circ} \mathrm{C}$.

TABLE 1

THE DILUTION OF SHEEP TISSUE HOMOGENATES FOR ENZYME ANALYSIS

\begin{tabular}{l|c|c|c|c|c|c|c}
\hline Homogenate* & $\begin{array}{c}\text { Alkaline } \\
\text { phosphatase }\end{array}$ & $\begin{array}{c}\text { Acid } \\
\text { phosphatase }\end{array}$ & GOT & $\begin{array}{c}\text { Lactic } \\
\text { dehydrogenase }\end{array}$ & Amylase & $\begin{array}{c}\text { Succinic } \\
\text { dehydrogenase }\end{array}$ & $\begin{array}{c}\text { Glucose-6- } \\
\text { phosphate } \\
\text { dehydrogenase }\end{array}$ \\
& 40 & 40 & 4 & 20 & ND & ND & 10 \\
Chorion & ND & 20 & 2 & 20 & ND & ND & 2 \\
Embryo & 20 & 20 & 4 & 40 & ND & ND & ND \\
Fluid & ND & 5 & ND & 5 & ND & ND & ND \\
\hline
\end{tabular}

* One volume of the homogenate (see Materials and Methods for preparation) or fluid was diluted to the above volume (ml) with calcium-free Krebs-Ringer-tris.

ND indicates that the homogenate or fluid was not diluted.

Succinic dehydrogenase was determined by the reduction of neotetrazolium chloride with sodium succinate as substrate (Eckstein, Kahan \& Borut, 1957; Sobel \& Eckstein, 1959). The succinic dehydrogenase activity of the homogenate was expressed as micrograms of neotetrazolium reduced during $20 \mathrm{~min}$ at $37^{\circ} \mathrm{C}$.

Spectrophotometric determination of the rate of NADPH formation was used for the assay of glucose-6-phosphate dehydrogenase (Warburg, Christian \& Griese, 1935). One unit of activity is the amount of enzyme in $1 \mathrm{ml}$ of sample which, at $25^{\circ} \mathrm{C}$ in a 3-ml assay mixture, changes the optical density of NADPH at $340 \mathrm{~m} \mu$ by 0.001 in $1 \mathrm{~min}$ (LaDue, Wroblewski \& Karmen, 1954).

The protein concentration of homogenates was determined by the biuret method (Wales, Scott \& White, 1961) and the dry weight was determined after $3 \mathrm{hr}$ at $105^{\circ} \mathrm{C}$.

Analyses of variance were done using the SILLIAC electronic computer and the within-group mean square was used to calculate standard errors of the difference between means for Student's $t$-tests. 


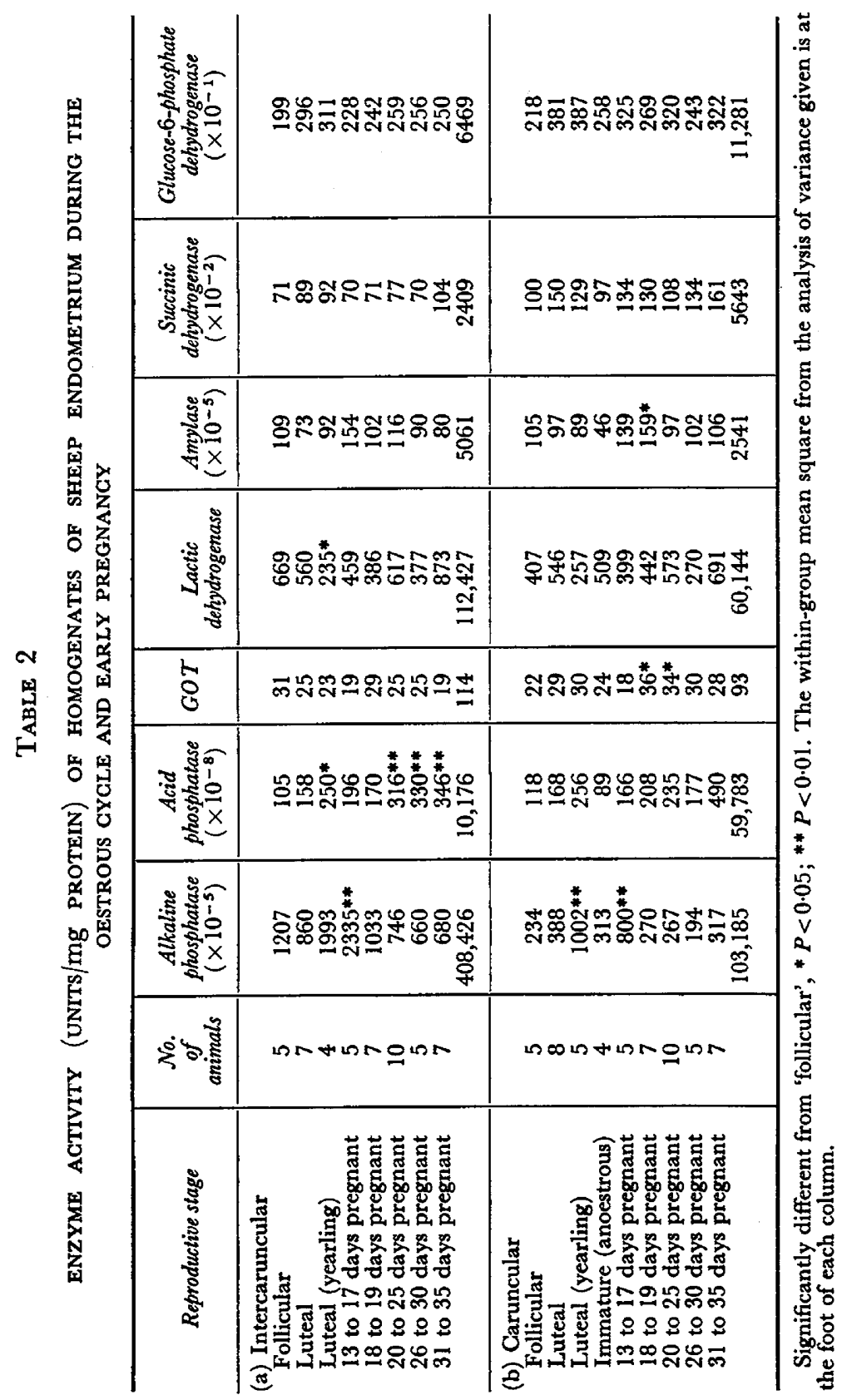




\section{Endometrial enzymes}

Table 2(a) shows the activity of some enzymes in the intercaruncular (glandular) area of the ewe endometrium during the follicular and luteal phases of the oestrous cycle and from Days 13 to 35 of pregnancy.

The activity of alkaline phosphatase rose to a maximum at Days 13 to 17 of pregnancy, decreased sharply on Days 18 and 19, and then declined steadily until Days 26 to 35 . A slower rise occurred in acid phosphatase activity, and high values were not attained until Days 20 to 35 when the alkaline phosphatase activity had fallen. The data suggest fluctuations in the levels of several enzymes, e.g. succinic dehydrogenase, during the oestrous cycle of the nonpregnant ewe and in yearling sheep; there were elevated levels of acid phosphatase and reduced levels of lactic dehydrogenase during the luteal phase when compared with those found during the follicular phase in ewes.

Table 2(b) gives data for enzymes estimated in the caruncular (nonglandular) area of the endometrium and also includes values obtained in a group of immature (anoestrous) ewes. The activity of the enzymes in the caruncular area was comparable to that found in the intercaruncular areas except that alkaline phosphatase activity was lower and succinic dehydrogenase was higher. The pattern of alkaline phosphatase activity in the caruncular area during pregnancy was similar to that in the intercaruncular area. A rise in the level of this enzyme also occurred in the caruncular area during the luteal phase of the oestrous cycle, particularly in the yearling sheep. The values for GOT were elevated from Days 18 to 25 of pregnancy while the same was true for amylase at Days 13 to 19. Adult and yearling females in the luteal phase of the oestrous cycle showed similar activities for the majority of enzymes in both the intercaruncular and caruncular tissue except for lower alkaline phosphatase and higher lactic dehydrogenase activity in the adult. In immature animals the caruncular area, in general, showed less activity of the various enzymes than did the adult in the luteal phase.

\section{Enzyme activity in chorion, blastocoelic fluid and embryo}

The activities of some enzymes in the chorion (Table 3) was variable, and none of the fluctuations in levels from Days 20 to 35 of pregnancy proved statistically significant.

All of the enzymes assayed could be detected in blastocoelic fluid (Table 3) with the exception of SDH; but the activity of most enzymes, e.g. GOT, LDH and GDH, was lower in the fluid than it was in the chorion. The only statistically significant change was a sharp rise in the acid phosphatase content of the blastocoelic fluid at Days 31 to 35 of pregnancy.

From the 20th to 35th day of gestation the crown-rump length of the embryos increased from 5 to $24 \mathrm{~mm}$. The results (Table 3) suggest that during this time a decrease in acid phosphatase and GOT activity may occur in the embryo, while LDH activity tends to increase. Compared to the chorion, the embryonic tissue had higher specific activities of alkaline phosphatase and SDH, and lower activities of acid phosphatase, amylase and GDH. 


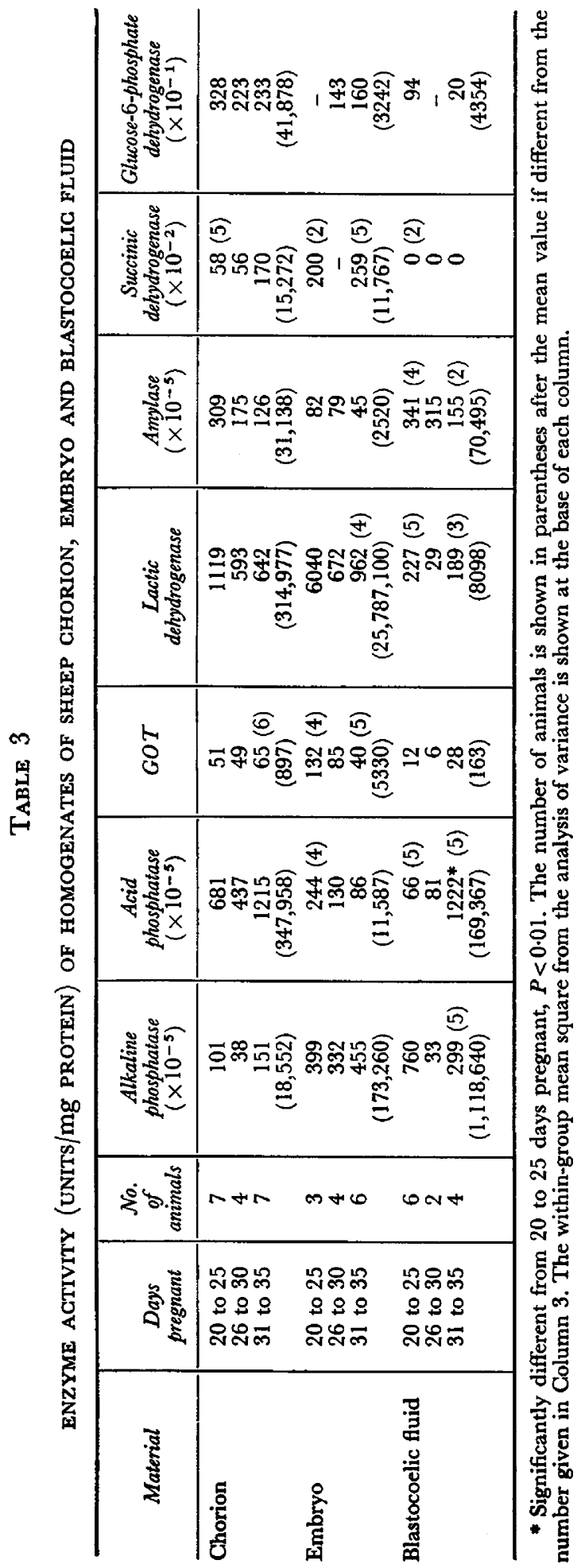




\section{DISCUSSION}

In this study an attempt has been made to determine enzyme activities at intervals closely associated with implantation. The precise time, however, of implantation in the ewe is difficult to define since it is a lengthy procedure (Green \& Winters, 1945; Amoroso, 1952).

If we take Days 20 to 25 p.c. as the time of implantation, then the most significant change found in the enzyme activities of intercaruncular and caruncular areas of the endometrium would appear to be a build-up of alkaline phosphatase and amylase before this, and a fall immediately before or during the implantation process contemporaneous with a rise in acid phosphatase and GoT. Implantation in the ewe may, therefore, entail a switch from alkaline to acid phosphatase in the endometrium and shifts in the pattern of carbohydrate and protein metabolism. A rise in the acid phosphatase of the blastocoelic fluid also occurs, but this is about 10 days after the expected time of implantation.

Since a rise in alkaline and acid phosphatase was observed during the luteal phase of the oestrous cycle, particularly in yearling sheep, it is probable that the increases observed in the pregnant animals are, at least in part, mediated through progesterone. Moss, Wrenn \& Sykes (1954) have observed a similar increase in endometrial alkaline phosphatase during mid-cycle in the cow but in non-ruminant species, e.g. human, rabbit and pig, activity is apparently stimulated by oestrogen rather than by progesterone (Atkinson \& Engle, 1947; Hall, 1950; Atkinson \& Elftman, 1947; Giering \& Zarrow, 1958; Goode, Warnick \& Wallace, 1965). The acid phosphatase content of the human and pig endometrium, like that of the ewe, is, on the other hand, increased by progesterone (Goldberg \& Jones, 1956; Goode, Warnick \& Wallace, 1965).

Cyclic changes have been shown to occur in the succinic dehydrogenase activity of the rat endometrium (Rosa \& Velardo, 1959b; Bever, Velardo, Telfer, Hisaw \& Goolsby, 1954) with maximal activity during the oestrogenic phase of the cycle (Rosa \& Velardo, 1959a). In our studies of the ewe, succinic dehydrogenase activity rose during the luteal phase but not significantly.

Amylase has been found in the oviducts and uterus of a number of species (McGeachin, Hargan, Potter \& Daus, 1958; Hafez \& White, 1967), and has recently attracted attention because of its possible role in the capacitation of spermatozoa (Kirton \& Hafs, 1965). The increase observed in the level of this enzyme in the endometrium of the ewe before implantation may possibly be related to making glucose readily available to the blastocyst; the increase in GOT activity of the endometrium may likewise be related to the amino acid requirements of the blastocyst.

In general, there appear to be no obvious correlations between our results for the ewe and those for the rabbit (Hafez \& White, 1967). The most striking changes in the rabbit endometrium were increases in SDH and GDH and a decrease in amylase which occurred when the doe became pregnant or pseudopregnant. This may be due in part, at least, to the different type of placentation; thus the rabbit, a polytocous species, has a haemochorial, and the sheep, a monotocous species, has a syndesmochorial placentation. The enzyme content of both the chorion and blastocoelic fluid of the sheep also differs from that of 
the rabbit (Hafez \& White, 1967), but this may be due to a difference in the maturity of the embryo rather than a true species difference.

\section{ACKNOWLEDGMENTS}

We wish to thank Professor C. W. Emmens for providing laboratory facilities and for his interest and advice and the U.S. National Institutes of Child Health and Human Development for a Special Fellowship (IF3 HD24, 411-01) while one of us (E.S.E.H.) was on sabbatical leave 1965/1966.

\section{REFERENCES}

Albers, H. J., Bedford, J. M. \& Ghang, M. C. (1961) Uterine peptidase activity in the rat and rabbit during pseudo-pregnancy. Am. 7. Physiol. 201, 554.

Amoroso, E. C. (1952) Placentation. In: Marshall's Physiology of Reproduction, Vol. 2, p. 127. Ed. A. S. Parkes. Longmans, Green, London.

ANDERsch, M. A. \& Szcypinski, A. J. (1947) The use of p-nitrophenylphosphate as substrate in determination of serum acid phosphatase. Am. F. clin. Path. 17, 571.

Atrinson, W. B. \& Elftman, H. (1947) Mobilization of alkaline phosphatase in the uterus of the mouse by glycogen. Endocrinology, 40, 30.

Atrinson, W. B. \& Engle, E. T. (1947) Studies on endometrial alkaline phosphatase during the human menstrual cycle and in the hormone-treated monkey. Endocrinology, 40, 327.

Bergmeyer, H. O. (1963) Methods of enzymic analysis. Academic Press, New York.

Bessey, O. A., Lowry, O. H. \& BRock, M. J. (1946) A method for the rapid determination of alkaline phosphatase with five cubic millimetres of serum. F. biol. Chem. 164, 321.

Bever, A. T., Velardo, J. T., Telfer, M. A., Hisaw, F. L. \& Goolsby, C. M. (1954) Changes in enzyme activity in uterus of rats during estrus cycle. Fedn Proc. Fedn Am. Socs exp. Biol. 13, 13.

Delgado, R. \& Fridhandler, L. (1964) Enzyme changes in the rabbit uterus in early pregnancy. Expl Cell Res. 34, 45.

Eckstein, B., Kahan, D. \& Borut, A. (1957) A modification of the tetrazolium reaction method for quantitative determination of dehydrogenase activity in tissues (preliminary note). Bull. Res. Coun. Israel, 6E, 189.

Giering, J. E. \& Zarrow, M. X. (1958) Changes in uterine morphology and phosphatase levels induced by chronic stimulation with the ovarian hormones. Acta endocr., Copenh. 29, 499.

GoldBerg, B. \& JoNEs, H. W., JR (1956) Acid phosphatase of the endometrium. Histochemical demonstration in various normal and pathological conditions. Obstet. Gynec., N.Y. 1, 542.

Goode, L., WARnick, A. C. \& WALLACE, H. D. (1965) Alkaline and acid phosphatase activity in the endometrium and ovary of swine. F. Anim. Sci. 24, 955.

Green, W. W. \& Winters, L. M. (1945) Prenatal development of the sheep. Bull. Minn. agric. Exp. Stn. 169.

HAFEz, E. S. E. \& White, I. G. (1967) Endometrial and embryonic enzymes in relation to implantation of the rabbit blastocyst. Anat. Rec. 159, 273.

Hall, J. E. (1950) Alkaline phosphatase in the human endometrium. Am. F. Obstet. Gynec. 60, 212.

Kirton, K. T. \& Hafs, H. D. (1965) Sperm capacitation by uterine fluid or beta-amylase in vitro. Science, N.Y. 150, 618.

LADUE, J. S., WROBLEWSKr, F. \& KARMEN, A. (1954) Serum glutamic oxalacetic transaminase activity in human acute transmural myocardial infection. Science, N.Y. 120, 497.

LUTWAK-MANN, C. (1955) Carbonic anhydrase in the female reproductive tract. Occurrence, distribution and hormonal dependence. F. Endocr. 13, 26.

LUTWAK-MANN, C. \& LASER, H. (1954) Bicarbonate content of the blastocyst fluid and carbonic anhydrase in the pregnant rabbit uterus. Nature, Lond. 173, 268.

Mageachin, R. L., Hargan, L. A., Potter, B. A. \& Daus, A. (1958) Amylase in fallopian tubes. Proc. Soc. exp. Biol. Med. 99, 130.

Moss, S., WrenN, T. R. \& SYkES, J. F. (1954) Alkaline phosphatase, glycogen and periodic acidSchiff positive substances in the bovine uterus during the estrous cycle. Endocrinology, 55, 261.

PRAHAld, K. V. (1962) A study of the rat $\beta$-glucuronidase prior to implantation in the ovum. Acta endocr., Copenh. 39, 407.

Reitman, S. \& Frankel, S. (1956) A colorimetric method for the determination of serum glutamic oxalacetic and glutamic pyruvic transaminases. Am. F. clin. Path. 28, 56. 
Rosa, G. G. \& Velardo, J. T. (1959a) Histochemical localization of vaginal oxidative enzymes and mucins in rats treated with estradiol and progesterone. Ann. N.Y. Acad. Sci. 83, 122.

Rosa, G. G. \& Velardo, J. T. (1959b) Histochemical observations of oxidative enzyme systems in the uterus and vagina of the rat. Ann. N.Y. Acad. Sci. 75, 491.

Sobel, H. \& Eckstern, B. (1959) Succinic dehydrogenase activity in brain tissue of rats after ovariectomy and steroid administration. Nature, Lond. 183, 54.

Street, H. V. \& Close, J. R. (1956) Determination of amylase activity in biological fluids. Clinica chim. Acta, 1, 256.

Wales, R. G., ScotT, T. W. \& Whrre, I. G. (1961) Biuret reactive materials in semen. Aust. J. exp. Biol. med. Sci. 39, 455.

Warburg, O., Christian, W. \& Griese, A. (1935) Wasserstoffübertragendes Co-Ferment seine zusanimensetzung und Wirkingsweisi, Biochem. Z. 282, 157.

Wroblewski, F. \& LADue, J. S. (1955) Lactic dehydrogenase activity in blood. Proc. Soc. exp. Biol. Med. 90, 210. 